\title{
Instrumental Analysis of the English Stops Produced by Arabic Speakers of English
}

\author{
Noureldin Mohamed Abdelaal* \\ Department of General Studies, Kolej Yayasan Pahang (KYP), 26060, Kuantan, Pahang, Malaysia
}

Corresponding author: Noureldin Mohamed Abdelaal, E-mail: Noureldin@kyp.edu.my

\begin{tabular}{l} 
ARTICLE INFO \\
\hline Article history \\
Received: June 03, 2017 \\
Accepted: July 18, 2017 \\
Published: July 31, 2017 \\
Volume: 5 Issue: 3 \\
\hline Conflicts of interest: None \\
Funding: None \\
\hline
\end{tabular}

\begin{abstract}
This study reports the findings of a research that was conducted on ten (10) Arab students, who were enrolled in a master of English applied linguistics program at Universiti Putra Malaysia. The research aimed at instrumentally analyzing the English stops produced by Arab learners, in terms of voice onset time (VOT); identifying the effect of their mother tongue on producing the English stops; and the extent Arabic speakers of English differentiate in terms of pronunciation between minimal pairs. The findings of the study showed that some of the subjects' VOT values were similar to native speakers of English. It was also found that the subjects could differentiate in terms of aspiration or voicing between $/ \mathrm{p} /$ and $/ \mathrm{b} /$, which refutes the assumption that Arab learners have a problem in producing the $/ \mathrm{p} /$ sound with appropriate aspiration. However, they did not show significant difference in pronunciation between the/t/and/d/or between the $/ \mathrm{k} /$ and $/ \mathrm{g} /$. Moreover, there is a kind of limited effect of the $\mathrm{L} 1$ on producing some stops (e.g./t/and $/ \mathrm{g} /$ ). However, for the $/ \mathrm{b} /$ sound, it cannot be inferred that there is interference from the mother tongue because its VOT value is almost the same in English and Arabic. This research suggests that teachers need to enhance Arab learners' pronunciation of some minimal pairs such as $/ t /$ and $/ \mathrm{d} /$ or $/ \mathrm{k} /$ and $/ \mathrm{g} /$.
\end{abstract}

Key words: Instrumental Analysis, English Stops, Arabic Speakers of English, Pronunciation

\section{INTRODUCTION}

English and Arabic are two distinctive languages which belong to two different language families. Arabic is a Semitic language while English is an Indo -European language, which postulates a contrast between the two languages in respect to syntax, morphology and phonology (Na'ama, 2011). The representation of the phonetic system in the two languages is different, as well (Al-Ani, 1970). For example, consonants and vowels are different in English from their counterparts in Arabic, which prompts some Arab learners mispronounce some English consonant sounds (Na'ama, 2011). It may be hypothesized that Arab learners have problems in producing the $/ \mathrm{p} /$ and $/ \mathrm{g} /$ sounds due to their lack of representation in the Arabic linguistic system. The problem is intensified by the complex syllable system of English, which splits syllables up into an onset and a rhyme; the rhyme, in turn, is split up into a vocalic nucleus and a coda. The coda contains all the postvocalic consonants, while the onset can vary in terms of the number of consonants (Wang, 2007). In relation to this, Avery and Ehrlich (1992) identified common pronunciation problems for most Arab L2 learners of English; among the problematic sounds identified is the $/ \mathrm{P} / \mathrm{stop}$ consonant, which is lacking in the Arabic linguistic system (Kopczynski \& Meliani, 1993). In a similar vein, Kopczynski and Meliani (1993) mentioned that the/g/sound does not exist in the Arabic sound system. Also, some other stops are represented differently in the two languages. For example, $/ \mathrm{t} / \mathrm{is}$ alveolar in English, but it is dental in Arabic (Kopczynski \& Meliani, 1993). These variations between English and Arabic lead to a hypothesis that Arabic speakers of English may not produce some of the English stops accurately, especially in terms of aspiration or voicing.

Over the past few decades, a considerable number of studies investigated voicing contrasts in stops employing the voice onset time (VOT), and which gradually became one of the most significant methods for examining timing of voicing in stops, especially in a word-initial position (Chao \& Chen, 2008). However, only a few attempts were made to examine VOT patterns among Arab learners who speak English as a second language (ESL).

Some studies have recently instrumentally analyzed the English vowel sounds produced by Arabic speakers of English (e.g. Al-Hamadi \& Ali, 2012; Ali, 2013; Hubais \& Pillai, 2010; Khalil, 2014); likewise, some studies instrumentally analyzed the consonants produced by nonnative speakers of English. For example, Mahmood, Asghar and Jabeen (2011) instrumentally examined the/ $\theta$ / and/ð/Sounds in Pakistani English; Yamaguchi and Pếtursson (2014) examined the voiceless stop consonants in Malaysian English. Although very few studies (e.g. Khattab, 2000) examined English VOT values among bilingual Arab children, and the English stop consonants produced 
by adult Arabic speakers (e.g. Flege \& Port, 1981), little is known about more recent studies that examine VOT values among Arab ESL learners. Employing instrumental analysis to measure pronunciation accuracy seems to be pivotal due to the fact that people have different abilities of perception, and thus they are not equal in their ability to identify the differences between the different utterances of different people. Moreover, so much consonant variation cannot be perceived by ear, which heightens the importance of employing instrumental work to gather accurate data (Lavoie, 2002). Lavoie stated that much more variation in consonants than expected was found because lexical knowledge and categorical perception both make it challenging to hear all of the variation that is present in consonants. Hence, it is important to examine spectrograms, in line with listening and transcribing the speech (Barry, 1996). Considering the fact that minimal pairs pose a challenge for second language learners (Smith, 2007). This study, therefore, aims to

1. identify the VOT values of the English stops produced by Arabic speakers of English, and the interference of their mother tongue; and

2. identify whether Arabic speakers of English can differentiate in terms of pronunciation between the minimal pairs of consonants.

\section{LITERATURE REVIEW}

\section{Previous Studies on Native, Bilingual, and Non-Native Speakers}

There are many studies which were conducted on native speakers starting from the major study of Lisker and Abramson (1964), who investigated the VOT for four American English speakers. They found that the VOT values of/ $\mathrm{p} /, / \mathrm{t} /, / \mathrm{k} /, / \mathrm{b} /, / \mathrm{d} /, / \mathrm{g} /$ were 58, 70, 80, 1, 5, $21 \mathrm{~ms}$, respectively. In their study of three Canadian English speaker, Macleod and Stoel-Gammon (2005) found that the VOT values of the voiced stops/b/,/d/and the voiceless stops/p/,/t/were 19.8 and $87.9 \mathrm{~ms}$, respectively. Kessinger and Blumstein (1997) examined the VOT of four English speakers; they found that the VOT values of/p/,/t/,/b/,/d/were 85, 100, 15, $20 \mathrm{~ms}$ respectively. Similarly, Klatt (1975) conducted a study on three English speakers, whereby he found that the VOT values for/b/,/d/,/g/were 11, 17, and $27 \mathrm{~ms}$, respectively; whereas the VOT values for/p/,/t/, and/k/were 47, 65, and $70 \mathrm{~ms}$, respectively. In a similar vein, Caruso and Burton (1987) investigated VOT among eight English speakers. They found that the VOT values of/p/,/t/,/k/,/b/,/d/,/g/were 62.5, 71.9, 74.8, 19.7, 21.4, $35.2 \mathrm{~ms}$. respectively.

In the context of bilinguals, Macleod and Stoel-Gammon (2005) conducted a study on three Canadian French speakers; they found that the VOT mean values of the voiced stops/b/,/d/and voiceless stops/p/,/t/were _ 99.3 and $37.4 \mathrm{~ms}$, respectively. In the context of nonnative speakers of English, the VOT values of four French speakers were examined by Kessinger and Blumstein (1997); they found that the values of/p/,/t/,/b/,/d/were 30, 35, $115,{ }_{-} 100 \mathrm{~ms}$, respectively.

\section{Previous Studies in Arabic Context}

Flege and Port (1981) examined various aspects of the production of voiceless stops (/p/,/t/, and/k/) among Saudi Arabic speakers learning English in the United States. They divided them into two groups of six participants each; the first group (Ar1) members had spent less than one year in the U.S., while the members of the second group (Ar2) had all spent more than a year in the U.S., with an average of 39 months of residency. For the purpose of comparing and contrasting, Flege and Port also examined the English stops among American native speakers of English. The recorded production of the voiceless stop consonants in initial position of all the three groups (i.e. the two Arabic speakers' groups and the American speaker's group) was analyzed in a carrier phrase using Pratt. Flege and Port found no significant difference among the two groups of the Arabic speakers; the group who had been living in US for long time (Average 39 month), and the group who had been living for less than a year. However, there was a significant difference between native Americans and Arabs. The following Table 1 summarizes their results (the standard deviation value is provided between brackets).

Similarly, Khattab (2000) conducted a study on monolingual and bilingual speakers of Arabic and English. Arabic speakers were from Lebanon. Khattab examined the VOT values in both English and Arabic. Among the monolingual Arabic participants, the VOT values for the Arabic/p/sound, which does not exist in Standard Arabic, ranged from 8 to23; for the Arabic $5 / \mathrm{k} /$ sound the VOT values ranged from 22 to 39 ; for the $ت / \mathrm{t} /$ sound, the VOT values ranged from 18 to 39 . However, she found negative VOT values for the/b/ب,/d/ د and $/ \mathrm{g} /$ sounds (note that the $/ \mathrm{g} /$ sound which does not exist in the Lebanese Arabic). Khattab found that the Arabic/b/sound had a negative VOT value which ranged from -30 to -57 ; the Arabic/d/sound had VOT values ranged from positive 5 to negative -56; and for/g/the VOT values ranged from positive 18 to negative -5 .

Among bilinguals (with English as dominant), Khattab found that the VOT values for the English/p/sound ranged from 40 to 90 ; for $/ \mathrm{k} /$, the VOT values ranged from 50 to 100 ; for/t/the VOT values ranged from 45 to 110 . As for the/b/sound, the VOT values ranged from negative -10 to positive $10 ; / \mathrm{d} /$ had values that ranged from negative -5 to positive 18; and/g/had VOT values that ranged from 25 to 30 .

English and Arabic vary in their VOT patterns. The VOT range for Arabic voiceless stops falls nearly within the range of voiced stops in English, while voiced Arabic stops and

Table 1. Production of voiceless stops (/p/, /t/, and /k/) among Arabic speakers (Flege \& Porte, 1981, p. 135)

\begin{tabular}{lccc}
\hline Voice onset time & $\begin{array}{c}\text { American } \\
\text { speakers } \\
\text { (group 3) }\end{array}$ & $\begin{array}{c}\text { Arabic } \\
\text { learners } \\
\text { (group 2) }\end{array}$ & $\begin{array}{c}\text { Arabic } \\
\text { learners } \\
\text { (group 1) }\end{array}$ \\
\hline$/ \mathrm{p} /$ in pat & $46(4)$ & $21(11)$ & $14(10)$ \\
$/ \mathrm{t} /$ in $\mathrm{tab}$ & $62(11)$ & $29(14)$ & $32(10)$ \\
$/ \mathrm{k} /$ in $\mathrm{cab}$ & $67(12)$ & $47(11)$ & $41(7)$ \\
\hline
\end{tabular}


voiceless English ones are each at an extreme end of the continuum (Khattab, 2000). AlDahri (2012) investigated the Arabic consonants/t/and/d/(د; ت) among Saudi students. He found that their VOT values were 65 and 16 respectively. He also found that Modern standard Arabic and Classical Arabic have short VOT for the voiced sounds, while voiceless sounds have long VOT. The VOT values found in modern standard Arabic of/b/,/d/,/k/, and/t/were 13, 14.75, 52, and 49 respectively.

\section{METHODS}

\section{Subjects}

Ten (10) Arab students constituted the sampling of this study. They were enrolled in an English applied linguistics master program in Universiti Putra Malaysia. To control for the proficiency level, respondents were selected according to their IELTS score, which is a requirement to enroll for the master's degree program; all of them had an overall band score of (6) in IELTS.

\section{Instruments}

Pratt software was utilized to record and analyze sounds of Arab speakers of English. They were analyzed in terms of the VOT (voice onset time).

\section{Measurements and Stimuli}

This study aimed at investigating the VOT of the English stops; thus, the target words were uttered in the carrier phrase "Say. again". The target words are: bat, pat, tap, dap, cap, and gap. The VOT value was measured for each respondent using Pratt software (Boersma \& Weenink, 2012).

\section{Procedures}

Subjects' utterances were recorded in a quiet room, using the Logitech noise- cancelling headset-built-in microphone connected to a laptop. Each recording was done and saved on the Pratt software at $2050 \mathrm{~Hz}$ sampling rate. The measurements were done on wideband spectrograms according to the procedure recommended by Lisker and Abramson (1964). After recording the sounds using Pratt, the recorded sounds were replayed and checked to ascertain the quality of the sound. Then, the recorded material was instrumentally analyzed to measure the VOT value for each stop consonant of each subject.

\section{RESULTS AND DISCUSSIONS}

The following Table 2 summarizes the mean VOT values of the English stops produced by the participants, and the standard deviation values. The letter ' $S$ ' is used to refer to the word 'subject' in this study.

As seen in Table 2 above, Arab learners of English seem to have a problem with some stop consonants. For example, the VOT mean values for/t/and/k/were found to be 44.5 and 59.2, respectively, which is below the values found among native speakers in the study of Lisker and Abramson (1964). The VOT value of the/g/is 34.2; this value is much longer than what is established in literature among some native speakers of English (e.g. Lisker \& Abramson, 1964; Macleod \& Steol-Gammon, 2005). However, this value is close to the value found by Caruso and Burton (1987) among eight English speakers. By contrast, the VOT values of/p/,/d/ and/b/were found to be $51.5,32.9$ and 5.1 , respectively. These values are native-like values (according to some literature among native speakers). They fall in the range of the average values. Detailed discussion is provided in the sections to follow.

\section{VOT of the Sounds}

\section{VOT of the /b/}

The VOT mean value of this sound was found to be 5.1, which is in the normal range found by Lisker and Abramson (1964). This basically shows that Arab speakers of English do not have problem with this sound. However, deeper look at the standard deviation shows that there is wide variation among the subjects (Figure 1).

As seen in the graph, wide variations among the subjects were found. For example, subject (S) 9 had a negative VOT of 99 , while S1 had, by contrast, VOT of $60 \mathrm{~ms}$. The mean value was $5.1 \mathrm{~ms}$, which follows Lisker and Abramson's categorization who mentioned in their study that the VOT value of $/ \mathrm{b} /$, in many languages, ranges from 20 to 25 . However, if each respondent's VOT value was individually examined, it will be noticed that some subjects' VOT values are not conformant with Lisker and Abramson's. For example, S1 has very long VOT (60 ms), while S7 and S9 have long negative VOT, that is, 53 and 93 , respectively. This may be attributed to the teaching methods employed in some Arab countries, as they tend to teach students produce the/b/sound

Table 2. Mean and Standard deviation of the English stops

\begin{tabular}{lcccccc}
\hline & $\boldsymbol{p}$ & $\boldsymbol{t}$ & $\boldsymbol{k}$ & $\boldsymbol{b}$ & $\boldsymbol{d}$ & $\boldsymbol{g}$ \\
\hline Mean & 51.5 & 44.5 & 59.2 & 5.1 & 32.9 & 34.2 \\
$\begin{array}{l}\text { Standard } \\
\text { deviation }\end{array}$ & 19.85 & 19.028 & 26.49 & 46.93 & 34.94 & 41.35 \\
\hline
\end{tabular}

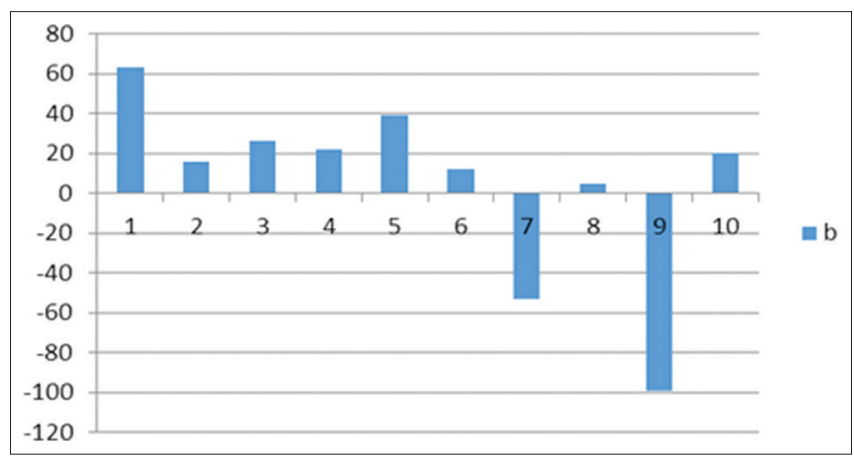

Figure 1. VOT of the /b/ 
either with much aspiration or with very low aspiration. Unsurprisingly, Khattab (2000) found that the VOT value for the/b/sound among young monolingual Arab subjects to be ranging from_30 to _57 which is conformant with S7 VOT value. The other subjects' VOT values were found as established in literature, either in Lisker and Abramson's study or other studies. In sum, it seems, as hypothesized, that Arab learners do not have a problem in pronouncing the/b/sound. It is noteworthy to mention that the VOT value of the/b/sound in Arabic is $14 \mathrm{~ms}$. (AlDahri, 2012); hence, Arab learners do not face difficulty in producing this sound. However, it is difficult to conclude that the mother tongue of the subjects contributed positively to their pronunciation of the sound. The subjects did not show a problem in producing the sound maybe due to its existence in their mother tongue linguistic system. This is a positive transfer, which was highlighted by Sabbah (2014), who mentioned that positive transfer occurs when learners use their mother tongue rules to help them use the second or foreign language.

\section{VOT of the /p/}

The mean VOT value of this stop was found to be 51.5. This value shows that there is a slight aspiration, as described by Chao and Ladefoged (1999); it does not fall under the aspirated sounds. Figure 2 below shows the VOT values that were found among the subjects.

As seen in Figure 2, the VOT values for half of the subjects (i.e. S3, S5, S8, S9, and S10) were found to be below $58 \mathrm{~ms}$. Few exceptions were found such as S2, whose VOT value hit $86 \mathrm{~ms}$; S4 had also a VOT of $63 \mathrm{~ms}$; and S6 whose VOT value was found to be $70 \mathrm{~ms}$. As mentioned earlier, the mean value of the VOT produced by the subjects was 51.5 , and the standard deviation was 19.85 , which is lower than the value found by Lisker and Abramson. However, this mean value is close to the findings of Chao and Ladefoged (1999) who found that the mean VOT value was around 50 ms.

Examining Figure 2, it is seen that S8 had the lowest VOT value among the subjects; her VOT value was found to be 15 ms. Also, S3 had a very low VOT value; that is, $39 \mathrm{~ms}$. S1 and S8 VOT values were found to be 58 and 59, respectively; these two values are conformant with Lisker and Abramson's study who found that the VOT mean value among American subjects as 58. They are also close to Cho and Ladefoged's (1999) findings who found that the VOT value for the aspirat$\mathrm{ed} / \mathrm{p} /$ is around $50 \mathrm{~ms}$. Therefore, against the common hypothesis that Arab learners have low VOT for the aspirated/p/; this study revealed that Arab learners do not have a problem in producing the/p/sound. Maybe an important factor which should be considered here is that the subjects are a master of English applied linguistics students; hence, they have great deal of command of the language and they might have practiced producing the English sounds well.

The VOT mean value, found by the researcher, is not so far from what was found in the literature among some native speakers. Although it is lower than the value found by Lisker and Abramson, it is conformant with Cho and Ladefoged's (1999) findings. Moreover, Flege and Port (1981) found the
VOT value for native American subjects to be $46 \mathrm{~ms}$, which implies that some respondents' VOT values are not far from the American VOT values. For example Peterson and Lehiste (1960) found that the VOT value for the/p/is 58. In sum, five subjects (i.e. S1, S2, S4, S6 and S7) out of 10 showed VOT values that are close to the findings of Lisker and Abramson (1964), while the other five subjects' VOT values were lower than the VOT values of Lisker and Abramson. These findings are not far from the findings of Khattab (2000) who found that the VOT value among bilinguals range from 40 to $90 \mathrm{~ms}$. To conclude, the Arab subjects in this study did not show a problem in producing the/p/sound.

\section{VOT of the /t/}

The mean VOT value for the/t/sound was found to be 44.5 . This value is lower than the value found by Lisker and Abramson or Chao and Ladefoged. The/t/sound is highly aspirated with an assumed-VOT value of around 90. Figure 3 summarizes the VOT values found among the 10 subjects of the study.

As seen in Figure 3, the highest VOT value was that produced by S4, whose VOT value was found to be $80 \mathrm{~ms}$. Similarly, S1 had a high VOT value of $62 \mathrm{~ms}$. Strikingly low VOT values were found among S8, S9, and S10; their VOT values were found to be 20,25 , and 33 respectively. The mean VOT value for the/t/sound was found to be 44.5 . This value is lower than the value established by Lisker and Abramson (70 ms). However, this value is close to its counterpart in Modern Standard Arabic (MSA), which was recorded by AlDahri as (49). This may lead to an assumption that there is

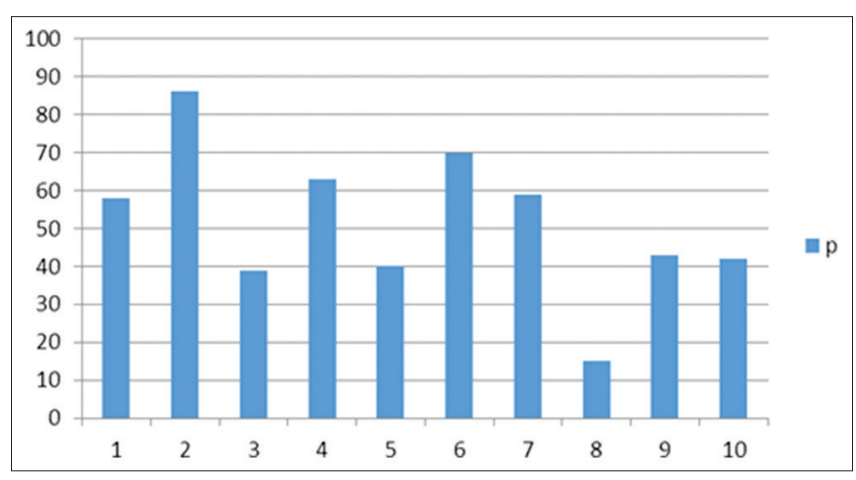

Figure 2. VOT values of the $/ \mathrm{p} /$ sound

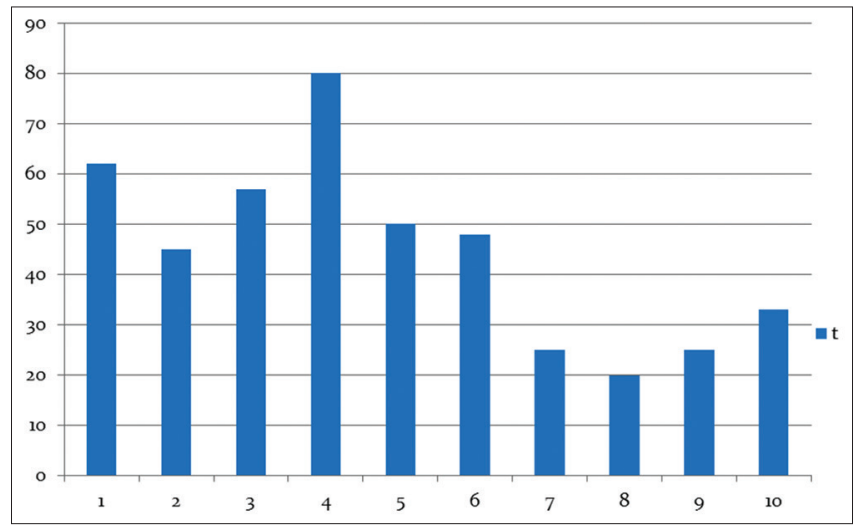

Figure 3. The VOT values of the $/ \mathrm{t} /$ sound 
interference of the mother tongue. These findings are in line with the findings of Khattab (2000), who found that the VOT value for the/t/among bilinguals, ranged from 45 to 110 . Surprisingly, the low VOT values correspond with the VOT values found among monolingual Arabic speakers, in which Khattab found the VOT values for the Arabic/t/sound ranged from 18 to 30 among monolingual speakers of Arabic. These findings suggest the Arab learners have low aspiration for the/t/sound, maybe due to interference of the mother tongue.

\section{VOT of the /d/}

The VOT mean value of the/d/sound was found to be 32.9. This value is close to the value found by Lisker and Abramson. Figure 4 summarizes the VOT values of $/ \mathrm{d} /$ found among the 10 subjects of the study.

As seen in Figure 4, the VOT values for most of the subjects are close to Lisker and Abramson's findings (30 ms.). The mean value of the VOT for/d/was found to be 32.9, while the standard deviation value was 34.93 , which is close to the literature. There are some subjects who surprisingly showed long VOT values. For example, S3 has the highest VOT value ( $73 \mathrm{~ms})$; then $\mathrm{S} 6$, whose VOT values was found to be 65 ; and $\mathrm{S} 1$ whose VOT was found to be $60 \mathrm{~ms}$.

In relation to the mother tongue, the English voiced stop/d/exists in the Arabic language sound system but with a lower VOT value than the English stop VOT value. It may sound interesting that the VOT value of the/d/sound for S7 is almost the same VOT value of his Arabic dialect $/ t /$ value (Jordanian dialect), as found by AlDahri (2012). By contrast, his VOT value of the English/t/is almost the same of the standard Arabic VOT of the $ت / t /($ i.e. $49 \mathrm{~ms}$.). It seems that he produces the/t/and/d/with the same aspiration, maybe this occurs due to the problem that many Arabic people pronounce/t/ and/d/interchangeably sometimes, with inclination to change the/t/to/d/. In sum, the Arab subjects did not show difficulty in producing the/d/sound/, and the interference of the mother tongue was not seen among most subjects, as though the MSA VOT value of the $\mathrm{s} / \mathrm{d} / \mathrm{sound}$ is 14.75 (A-Dahri, 2012.), the subjects mostly did not follow the same pattern.

\section{VOT of the $/ \mathrm{k} /$}

The mean value of the VOT for the/k/sound is 59.2 , which is below the value found by Lisker and Abramson. Figure 5 summarizes the VOT values of $/ \mathrm{k} /$ found among the 10 subjects of the study.

As seen from the graph, and examining the VOT values for each subject, it was found that S4 had the highest VOT value for the/k/sound (93); $\mathrm{S} 3$ also had a VOT value of 90; S1 had a VOT value of 78; S2, S5 and S6 had VOT values which were 75,67 , and 69 , respectively. All the subjects seem to have VOT values which are not so divergent from Lisker and Abramson's findings, and in line with Khattab's findings of the VOT values among bilinguals. By contrast, the VOT values for $\mathrm{S} 7, \mathrm{~S} 8, \mathrm{~S} 9$, and $\mathrm{S} 10$ were found as 30 , $32,34,24$, respectively; which are so divergent from the VOT values found in Lisker and Abramson's study. By contrast, it was close to Khattab's findings among bilinguals, whose VOT ranged from 50 to 100 . These findings are also close to MSA counterpart, in which the VOT value s found by AlDahri (2012) as (52). Hence, it can be assumed that there might be interference of the mother tongue in producing this sound.

\section{VOT of the $/ g /$}

The mean VOT value found among the subjects is 34.2, which is not conformant with Lisker and Abramson's findings (i.e. 18). The following graph summarizes the VOT values of $/ \mathrm{g} /$ found among the 10 subjects of the study.

As seen in Figure 6, S3 and S9 had a VOT value of 98; while S1 had a VOT value of 40. By contrast, S7 had a

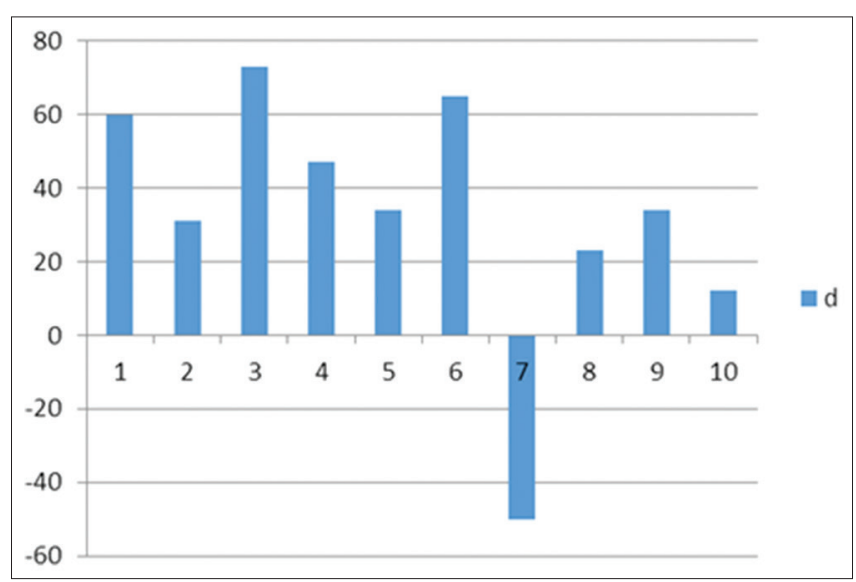

Figure 4. VOT of /d/ sound

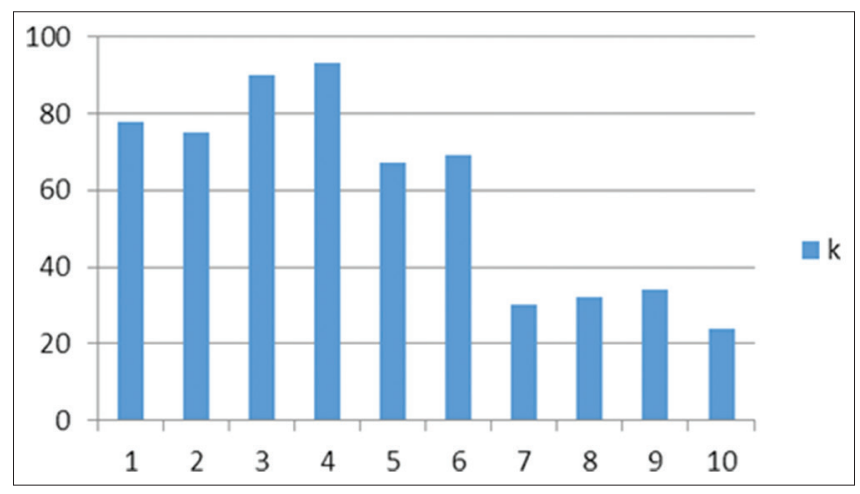

Figure 5. VOT of $/ \mathrm{k} /$

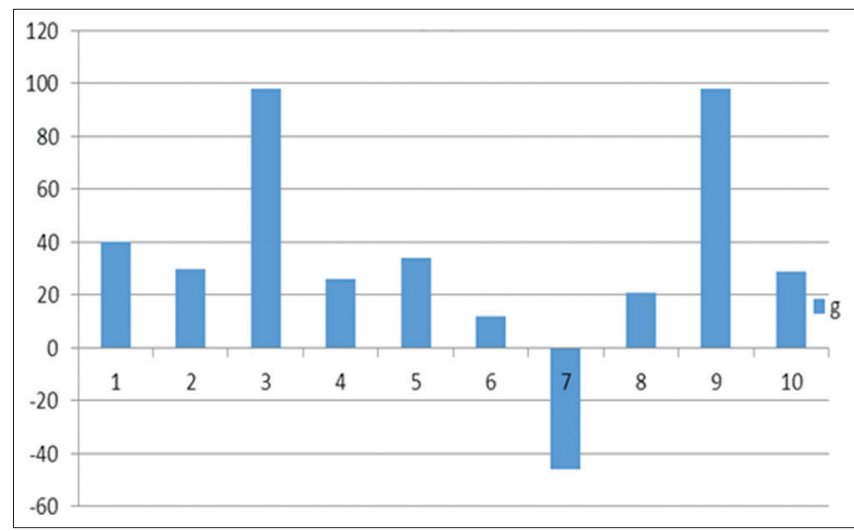

Figure 6. The VOT values of the /g/ sound 
negative VOT value of 46 . These values are highly divergent from Lisker and Abramson's study, in which the VOT value for/g/was around $18 \mathrm{~ms}$. So, it can be said that the VOT values are not in accordance with the literature and with Lisker and Abramson's findings among native speakers. It is noteworthy to mention that this sound is not represented in the Arabic sound system, which might cause a difficulty in its pronunciation.

\section{Comparison of VOT Values of Voiced and Voiceless Stops}

A paired-samples t-test was conducted to compare the VOT values of the voiced and voiceless stops. The results were found as below:

\section{Comparison of VOT values of $/ \mathrm{b} /$ and $/ p$}

The following Table 3 illustrates the statistical differences in values between $/ \mathrm{b} /$ and $/ \mathrm{p}$

As seen from the table above, p-value was at 0.015 , which is statistically significant at $p<.05$. This indicates that the Arab subjects could differentiate between the aspirated voiceless $/ \mathrm{p} /$ and the unaspirated voiced/b/. These findings are in line with Flege and Port (1981), who found that although the VOT value of the $/ \mathrm{p} /$ sound was lower than American native speakers, the VOT values' differences between the/p/ and/b/indicate that Arab subjects can differentiate in terms of voicing or aspiration between the two sounds (i.e. the voiced and the voiceless).

\section{Comparison of VOT values of $/ t /$ and $/ d$}

The following Table 4 illustrates the statistical differences in VOT values of $/ \mathrm{t} /$ and $/ \mathrm{d}$

As seen from the table above, p-value was at 0.22 , which is statistically insignificant at $p>.05$. This indicates that Arab subjects could not differentiate between the aspirated voiceless/t/and the unaspirated voiced/d/.

\section{Comparison of VOT values of $/ \mathrm{k} / \mathrm{and} / \mathrm{g}$}

The following Table 5 illustrates the statistical differences in values between $/ \mathrm{k} / \mathrm{and} / \mathrm{g} /$.

As seen from the table above, p-value was at 0.095 , which is statistically insignificant at $\mathrm{P}-$ Value $<0.05$. This indicates that Arab the subjects could not differentiate between the aspirated voiceless/k/and the unaspirated voiced $\mathrm{g} /$.

\section{CONCLUSION}

This study aimed at instrumentally analyzing the English stops produced by adult Arabic speakers who were English majors, and the effect of the mother tongue on producing the English stops. The findings of the study showed that the Arab subjects differentiated in terms of aspiration or voicing between/p/and/b/. However, they did not show significance difference between the/t/and/d/or between/ $/ \mathrm{and} / \mathrm{g} /$. Moreover, there is a kind of limited effect of the L1 on produc-
Table 3. Comparison of $/ \mathrm{b} /$ and $/ \mathrm{p} /$

\begin{tabular}{lcc}
\hline & b & p \\
\hline Mean & 5.1 & 51.5 \\
Standard deviation & 46.93 & 19.8583 \\
Significant value $(p)$ & $0.015^{*}$ & \\
\hline
\end{tabular}

$* p$-value significant at 0.05

Table 4. Comparison of /t/ and /d/

\begin{tabular}{lcc}
\hline & b & p \\
\hline Mean & 44.5 & 32.9 \\
Standard deviation & 19.03 & 34.94 \\
Significant value $(p)$ & 0.22 & \\
\hline
\end{tabular}

Table 5. Comparison of $/ \mathrm{k} / \mathrm{and} / \mathrm{g} /$

\begin{tabular}{lcc}
\hline & b & p \\
\hline Mean & 59.2 & 34.2 \\
Standard deviation & 26.49 & 41.35 \\
Significant value $(p)$ & 0.095 & \\
\hline
\end{tabular}

ing some stops (e.g./t/ and /g/). However, for/b/ sound, we cannot infer that there is interference of the mother tongue because its VOT value is almost the same in English and Arabic. This study suggests that future studies to be conducted on L2 learners with different disciplines. It is also suggested controlling for the different Arabic dialects as a variable; future studies can, also, compare the English stops produced by Arab speakers of English of different dialectal backgrounds.

\section{ACKNOWLEDGMENT}

This article is completely funded by Kolej Yayasan Pahang (KYP), 26060, Kuantan, Pahang, Malaysia.

\section{REFERENCES}

Al-Ani, S.H. (1970). Arabic Phonology. Hague, Netherlands: Mouton \& CO, N.V. Publishers.

AlDahri, S. (2012). A Study of Voice Onset Time for Modern Standard Arabic and Classical Arabic. The 2012 IEEE International Conference on Signal Processing and Computing, 691-695. Retrieved from http://scholar.google. $\mathrm{com} / \mathrm{scholar}$ hl=en\&btnG=Search\&q=intitle: a+study+of+voice+onset+time+for+modern+standard+Arabic+and+classical+Arabic $\# 0$.

Al-Hamadi, H., \& Ali, F. (2012). Acoustic Analysis of English Pure Vowels in Clear and Conversational Speech : An Experimental Study at the University of Basra Arab Gulf Journal, 4, 3-4.

Ali, E. (2013). Pronunciation problems : Acoustic analysis of the English vowels produced by Sudanese learners of English. International Journal of English and Literature, 4(10), 495-507. doi:10.5897/IJEL12.031.

Amer, W. (2001). An investigation into the Differences between English and Arabic Consonant and Vowel 
Sounds: A Contrastive Study with Pedagogical Implications. Site.iugaza.edu.ps, 1-20. Retrieved from http:// site.iugaza.edu.ps/wamer/files/2010/02/An-investigation-into-the-Differences-between-English-and-Arabic-Consonant-and-Vowel-Sounds-review.pdf.

Auzou, P., Özsancak, C., Morris, R.J., Jan, M., Eustache, F. and Hannequin, D. (2000). Voice onset time in aphasia, apraxia of speech and dysarthria: a review. Clinical Linguistics and Phonetics, 14(2): 131-150.

Avery, P., and Ehrlich, S. (1992). Problems of Selected Language Groups in Avery, P., and Ehrlich, S. in Teaching American English Pronunciation. Oxford University Press.

Barros, A. (2003). Pronunciation Difficulties in the Consonant System Experienced by Arabic Speakers When Learning English after the Age of Puberty. Unpublished M.A. Thesis West Vergina University.

Barry, W.J. (1996). Some fundamental problems of looking at connected speech. Arbeitsberichte 31. Institut für Phonetik und Digitale Sprachverarbeitung, Kiel University, 113-118.

Boersma, Paul, Weenink, David. (2009). Praat: doing phonetics by computer (Version 5.1.05) [Computer program]. Retrieved from May 1, 2009 http://www.praat org/.

Caruso, A., Burton, E. (1987). Temporal acoustic measures of dysarthria associated with amyotrophic lateral sclerosis. Journal of Speech and Hearing Research, 30, 80 -87.

Chao, K., \& Chen, L. (2008). A cross-linguistic study of voice onset time in stop consonant productions. Computational Linguistics and Chinese Language Processing, 13(2), 215-232. Retrieved from http://www.aclweb.org/ anthology/O/O08/O08-4005

Cho, T., \& Ladefoged, P. (1999). Variation and universals in VOT: evidence from 18 languages. Journal of Phonetics, 27(2), 207-229. doi:10.1006/jpho.1999.0094

Docherty, G. (1992). The Timing of Voicing in British English Obstruents. Foris, New York.

Fischer-Jorgensen, E. (1954). Acoustic Analysis of Stop Consonants. Miscellena Phonetica 2, 42-59.

Flege, J., \& Port, R. (1981). Cross-language phonetic interference: Arabic to English. Language and Speech, 24, 125-146. doi:10.1177/002383098102400202

Hubais, A., \& Pillai, S. (2010). An instrumental analysis of English vowels produced by Omanis. Journal of Modern Languages, 20, 1-18.

Kessinger, R., Blumstein, S. (1997). Effects of speaking rate on voice-onset time in Thai, French, and English. Journal of Phonetics, 25, 143-168.

Khalil, S. (2014). Comparative Study of the Acoustic Vowel Space of Egyptian English Vowels and General American English Vowels. Linguistic Portfolios, 3.

Khattab, G. (2000). VOT production in English and Arabic bilingual and monolingual children. Leeds Working Papers in Linguistics and Phonetics, 95-122.

Klatt, D.H. (1975). Voice onset time, frication and aspiration in word initial consonant clusters. Journal of Speech and Hearing Research18, 686-705.
Klein, M. (1981). Aspir (at) ing to Speak like a Native: Tracking Voice Onset Time in the Acquisition of English Stops. Gmu.edu, 1261-1271. Retrieved from http:// www.gmu.edu/org/lingclub/WP/texts/9_MikeKlein.pdf.

Klein, M. (2011). Aspir (at) ing to Speak like a Native: Tracking Voice Onset Time in the Acquisition of English Stops. Gmu.edu, 4(4), 131-136. doi:10.5539/ies. v4n4p131

Kopczynski, A., \& Meliani, R. (1993). The consonants of Arabic and English. Papers and Studies in Contrastive Linguistics.

Ladefoged, P. (1975). A Course in Phonetics. New York: Hacourt Brace Jovanovich, Inc.

Lavoie, L. (2002). Subphonemic and suballophonic consonant variation: The role of the phoneme inventory. $Z A S$ Papers in Linguistics, 39-54.

Lisker, L. and A.S. Abramson. (1967). Some effects of context on voice onset time in English stops. Language Speech, 10, 1-28.

Lisker, L., \& Abramson, A.S. (1964). A cross-language study of voicing in initial stops: acoustical measurements. Word, 20,384-422.

Macleod, A, \& Stoel-Gammon, C. (2005). Are bilinguals different? What VOT tells us about simultaneous bilinguals. Journal of Multilingual Communication Disorders 3(2), 118-127.

Mahmood, M. A., Asghar, M., \& Jabeen, F. (2011). Acoustic Analysis of/?/and/ð/Sounds in Pakistani English. International Education Studies, 4(4), 131-136. doi:10.5539/ ies.v4n4p131

Major, R. C. (1987 . English voiceless stop production by speakers of Brazilian Portuguese. Journal of Phonetics, 15, 197-202.

Morley, J. (1991). The pronunciation component in teaching English to speakers of other languages. TESOLQuarterly, 25(3), 481-520.

Na'ama, A. (2011). An Analysis of Errors Made By Yemeni University Students in the English Consonant-Clusters System. Damascus University Journal, 27(3), 145-161. Retrieved from https://goo.gl/uLgb6v.

Nair, R., Krishnasamy, R., \& Mello, G. De. (2006). Rethinking the teaching of pronunciation in the ESL classroom. The English Teacher, XXXV, 27(1999), 27-40. Retrieved from http://melta.org.my/ET/2006/2006_3.pdf.

Nasr, R. (1967). The structure of Arabic from Sound to Sentence. Beirut; Libraire du Liban.

Öğüt, F., Kiliç, M. A., Engin, E. Z., \& Midilli, R. (2006). Voice onset times for Turkish stop consonants. Speech Communication, 48(9), 1094-1099. doi:10.1016/j. specom.2006.02.003.

Peterson, G. E., \& Lehiste, I. (1960). Duration of syllable nuclei in English. The Journal of the Acoustical Society of America, 32(6), 693-703.

Port, R.F. and Rotunno, R. (1979). Relation between voice-onset time and vowel duration. Journal of the Acoustical Society of America, 66, 654-662.

Puskás, G., \& Schmitz, C. (2005). Phonetics and Phonology. Geneva: University of Oldenburg, 1-64. 
Sabbah, S. (2015). Negative Transfer: Arabic Language Interference to English Learning. Arab World English Journal, 4, 269-288 Retrieved from https://goo. gl/7i5Qwi.

Smith, B. Arabic Speakers (2007). In Swan, M \& Smith, B. Learner English: A teacher's guide to interference and other problems. Cambridge Handbook for Language Teachers. CUP.

Varasarin, P. (2007). An Action Research Study of Pronunciation Training, Language Learning Strategies and Speaking Confidencell. (PhD dissertation). School of Education Faculty of Arts, Education and Human Development Victoria University.
Wang, H. (2007). English as a lingua franca: Mutual Intelligibility of Chinese, Dutch and American speakers of English. Utrecht: LOT.

Ward, IAD C. (1971) The phonetics of English (5 $5^{\text {th }}$ ed.), Cambridge: Cambridge University Press

Weismer, G. (1979). Sensitivity of voice-onset-time (VOT) measures to certain segmental features in speech production. Journal of Phonetics, 7, 197-204.

Yamaguchi, T., \& Pétursson, M. (2014). Voiceless Stop Consonants in Malaysian English. Asian Englishes, 15(2), 37-41. doi: 10.1080/13488678.2012.10801330.

Yule, G. (2009). The study of language. Cambridge: Cambridge University Press. 